\title{
Hotel Manajer: Permainan Simulasi Manajemen Operasi Hotel dengan Pemodelan Finite State Machine
}

\author{
Agung Teguh Setyadi, Imam Kuswardayan, dan Ridho Rahman H \\ Departemen Informatika, Fakultas Teknologi Informasi dan Komunikasi, Institut Teknologi Sepuluh \\ Nopember (ITS) \\ e-mail: ridho@its.ac.id
}

\begin{abstract}
Abstrak-Permainan simulasi adalah permainan yang dirancang untuk mensimulasikan aktivitas dunia nyata dengan seksama. Salah satunya adalah permainan simulasi manajemen hotel. Manajemen hotel sendiri merupakan suatu aktivitas dalam mengolah proses bisnis hotel mulai dari merekrut karyawan, membangun fasilitas atau kamar, mengatur harga sewa serta cara meningkatkan kepuasan tamu. Dalam penelitian ini penulis ingin membangun permainan simulasi manajemen hotel dengan menggunakan pemodelan Finite State Machine (FSM). Pada permainan ini, FSM akan digunakan sebagai diagram model bisnis. Permainan simulasi ini akan berjalan pada program desktop Windows. Pengujian pengguna pada permainan mendapatkan nilai 3.01 dari skala 4 untuk parameter manajemen hotel. Dari hasil uji coba tersebut, dapat dikatakan permainan telah mensimulasikan proses bisnis manajemen hotel dengan baik. Dengan pengujian blackbox, permainan telah mengimplementasikan aturan dan skenario permainan simulasi manajemen hotel dengan Finite State Machine.
\end{abstract}

Kata Kunci-Permainan Simulasi, Manajemen Hotel, Perangkat Dekstop, Finite State Machine, Sistem Operasi Windows.

\section{PENDAHULUAN}

$\mathrm{D}$ EWASA ini aplikasi permainan sangat populer dikalangan masyarakat. Berberapa aplikasi permainan digunakan sebagai sarana hiburan maupun sarana edukasi baik oleh kaum anak-anak ataupun orang dewasa. Salah satu genre aplikasi permainan yang mengandung unsur hiburan dan edukasi adalah genre simulasi. Simulasi sendiri adalah suatu proses pengimitasian proses dari kejadian nyata. Jadi permainan simulasi adalah permainan yang bertujuan agar penggunanya dapat mengetahui lingkungan dari proses yang disimulasikan tanpa harus mengalami efek pengambilan keputusan dalam dunia nyata [1].

Pekerjaan yang cukup diminati dewasa ini salah satunya adalah manajemen hotel. Manajemen hotel merupakan kegiatan megolah operasi hotel yang mencakup pengelolaan staf hotel, manajemen bisnis, pemeliharaan dan standar kebersihan fasilitas hotel, kepuasan tamu dan layanan pelanggan, manajemen penjualan, manajemen pendapatan, akuntansi keuangan, pembelian, dan lainnya [2].

Penelitian ini merancang dan membangun suatu permainan yang bergenre simulasi dengan tema manajemen hotel menggunakan model Finite State Machine (FSM). FSM adalah sebuah metodologi perancangan sistem kontrol yang menggambarkan tingkah laku atau prinsip kerja sistem dengan menggunakan 3 komponen yaitu state (keadaan), event (kejadian), dan action (aksi). Permainan ini akan mensimulasikan proses bisnis dari manajemen hotel. Permainan ini akan dijalankan dan dimainkan pada perangkat desktop dengan sistem operasi Windows. Permainan ini diberi nama Hotel Saya.

\section{TINJAUAN PUSTAKA}

\section{A. Game Maker Studio}

Game Maker Studio merupakan game engine untuk pembuatan game 2D yang dibuat oleh perusahaan bernama YoYoGame. Konsep yang digunakan adalah visual coding interface berbasis drag and drop, sehingga mudah untuk dipelajari dan digunakan oleh pemula. Game Maker menyediakan bahasa pemograma, yaitu GameMaker Language (GML). Versi Master dari Game Maker Studio dapat digunakan dalam membuat aplikasi untuk berbagai macam platform seperti Android, HTML5, iOS, Playstation Vita, Playstation 3, Playstation 4, Xbox ONE, Ubuntu, Windows dan platform-platform lain[3].

\section{B. Finite State Machine}

Finite State Machine (FSM) merupakan metodologi perencanaa sistem control yang mendeskripsikan tingkah laku sistem yang bekerja menggunakan 3 prinsip yaitu state, event, action.

Tabel 1 Simbol Pada FSM

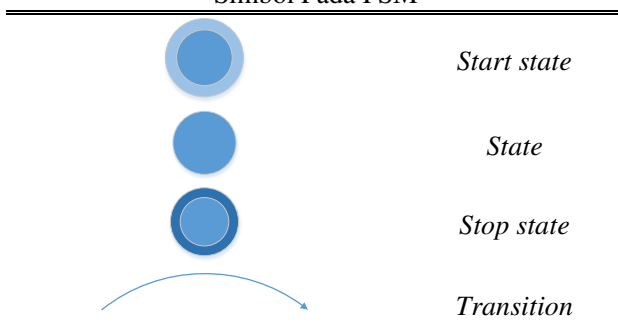

Sistem dapat berganti ke state yang lain jika mendapatkan input yang telah ditentukan atau karena sebuah event yang berasal dari device eksternal atau komponen sistem itu sendiri. Kondisi perpindahan ini umumnya diikuti dengan sebuah action[4]. 


\section{Manajemen Hotel}

Manajemen hotel merupakan kegiatan megolah operasi hotel yang mencakup pengelolaan staf hotel, manajemen bisnis, pemeliharaan dan standar kebersihan fasilitas hotel, kepuasan tamu dan layanan pelanggan, manajemen penjualan, manajemen pendapatan, akuntansi keuangan, pembelian, dan lainnya[2].

Hotel diklasifikasi menjadi berberapa bagian salah satunya pengklasifikasian berdasarkan bintang. Berikut klasifikasi hotel berdasarkan bintang. Hotel dengan bintang 1 merupakan hotel yang relatif kecil jumlah kamar standar minimum 15 kamar. Hotel dengan bintang 3 merupakan hotel yang berada pada tempat strategis dan cukup luas. Pelayanan pada bintang 3 harus baik. Terdapat berberapa fasilitas pada hotel bintang 3 yaitu sarana olahraga seperti kolam renang, restaurant, dan kamar standar minimum 30 kamar. Pada hotel bintang 3 terdapat jenis kamar yang lebih bagus pada kamar standard. Hotel dengan bintang 5 merupakan hotel yang besar dan mempunyai fasilitas yang cukup lengkap seperti adanya lobby, taman-taman, kolam renang, dll. Kamar yang tersedia lebih banyak[5].

Untuk meningkatkan kepuasan tamu hotel maka pihak hotel diharuskan melayani tamu dengan baik seperti menjaga kebersihan hotel, menjaga keamanan hotel dan memberikan pelayanan resepsionis yang baik. Maka dari itu pihak hotel akan merekrut pegawai yang masing-masing memiliki tugas yang berbeda dan tentunya masing-masing memiliki gaji yang berbeda pula. Hotel pada umumnya terdiri dari empat pegawai yaitu pelayan atau koki restoran, resepsionis, pembersih, dan satpam [6].

\section{METODE PENELITIAN}

\section{A. Model FSM Pada Permainan Simulasi Manajemen Hotel}

Pada halaman permainan terdapat pointer yang berguna untuk membangun atau menghancurkan bangunan hotel. Ada tiga pointer yang pertama pointer cursor berguna untuk mengklik tombol menu yang ada pada permainan, kedua pointer bangunan berguna ketika pemain ingin membangun bangunan, dan yang ketiga pointer delete berguna ketika pemain ingin menghancurkan bangunan.

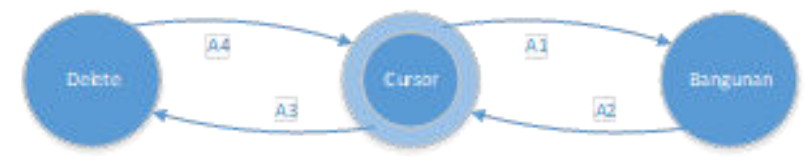

Gambar 1. FSM pointer permainan.

Pada Gambar 1 A1 merupakan ketika pemain memilih tipe bangunan pada menu bangunan. Bangunan akan berupa tipe bangunan yang sesuai dipilih pemain. A2 merupakan ketika pemain mengarahkan cursor ke menu bar atau ketika pemain mengeklik menu cursor. A3 merupakan ketika pemain mengeklik menu delete. Sedangkan A4 ketika kursor pemain berada pada menu bar atau pemain mengeklik menu cursor.

Dalam permain, pemain dapat memperluas hotel untuk menambah area pembangunan hotel. Terdapat 2 cara memperluas hotel yaitu dengan meningkat hotel atau membeli tanah dengan catatan pemain memiliki uang yang cukup. Gambar 2 memperlihatkan FSM memperluas hotel.

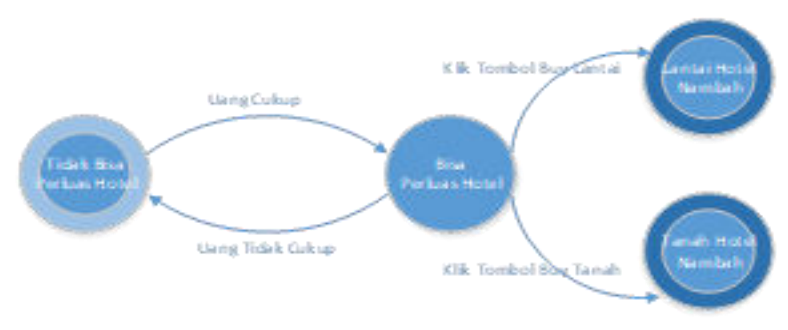

Gambar 2. FSM memperluas hotel.

Pemain dapat merekrut pegawai untuk melayani tamu agar tamu merasa senang dalam hotel. Jika uang dari si pemain cukup untuk merekrut pegawai maka pemain dapat merekrut pegawai. Gambar 3 memperlihatkan FSM merekrut pegawai.

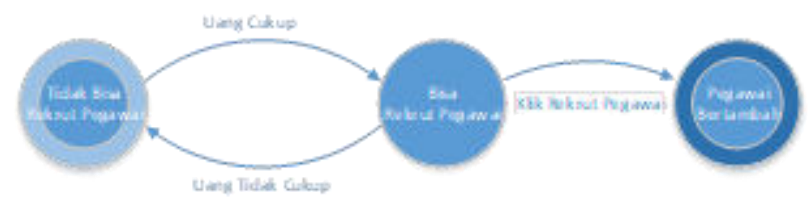

Gambar 3. FSM merekrut pegawai.

Pada saat pemain merekrut pegawai, pegawai memiliki kondisi mood yang berpengaruh terhadap kecepatan kerja. Jika variabel mood pegawai lebih dari $51 \%$ maka kecepatan pegawai dalam melakukan pekerjaan akan dikatakan normal namun ketika kurang dari 50\% maka kecepatan pegawai dalam melakukan kerja akan melambat. Naik dan turunnya mood pegawai dikarenakan pegawai berkerja secara terus menerus. Gambar 4 FSM memperlihatkan kondisi kecepatan kerja pegawai.

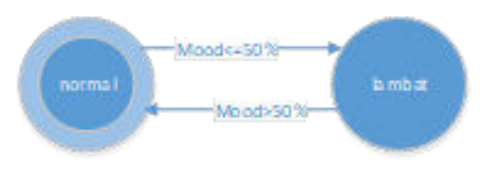

Gambar 4. FSM kondisi kecepatan kerja pegawai.

Tamu pada permainan simulasi hotel mempunyai rasa senang, normal, dan kecewa. Naik turunnya kesenangan tamu dipengaruhi oleh atribut kenyamanan yang ada pada tamu. Sedangkan atribut kenyamanan sendiri naik turunnya dipengaruhi oleh kualitas pelayanan hotel dan kelengkapan fasilitas pada hotel. Kondisi tamu ini akan berpengaruh pada reputasi hotel. Jika tamu kecewa maka reputasi hotel akan menurun tetapi jika tamu senang reputasi hotel akan meningkat. Gambar 5 memperlihatkan FSM kondisi Tamu.

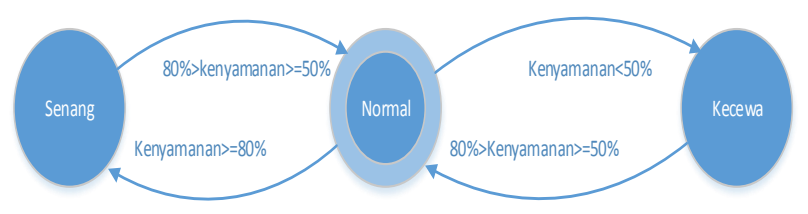


Gambar 5. FSM kondisi tamu.

Terdapat atribut kenyamanan pada setiap tamu untuk menentukan senang atau tidaknya tamu. Atribut kenyamanan tamu ini dipengaruhi oleh berberapa faktor yaitu keindahan, keamanan, kelengkapan fasilitas hotel dan kebersihan. Berikut Gambar 6 yang memperlihatkan FSM kondisi berkurang atau bertambahnya kenyamanan tamu.

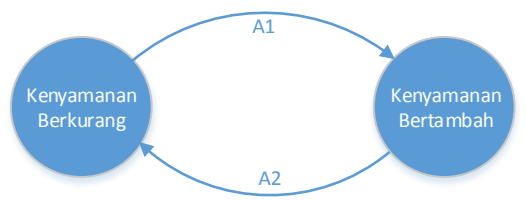

Gambar 6. FSM kenyamanan tamu.

Pada Gambar 6 A1 menunjukan kenyamanan tamu akan bertambah jika tidak ada maling di hotel, sampah yang ada di hotel sedikit, fasilitas hotel lengkap, dan ada bangunan dekorasi pada hotel. A2 menunjukkan kenyamanan tamu akan berkurang jika banyak maling yang tidak tertangkap pada hotel, sampah pada hotel tidak dibersihkan, fasilitas hotel kurang lengkap, dan tidak adanya dekorasi seperti taman pada hotel.

Tamu pada permainan simulasi hotel memiliki perilaku yaitu pertama tamu akan berjalan mencari resepsionis dan tamu kemudian mencari kamar yang kosong. Dari kamar ada tamu yang langsung pulang tanpa menggunakan fasilitas hotel. Ada juga tamu yang menggunakan fasilitas hotel. Jika tamu sudah selesai berkunjung maka tamu akan pulang. Berikut Gambar 7 memperlihatkan FSM perilaku tamu.

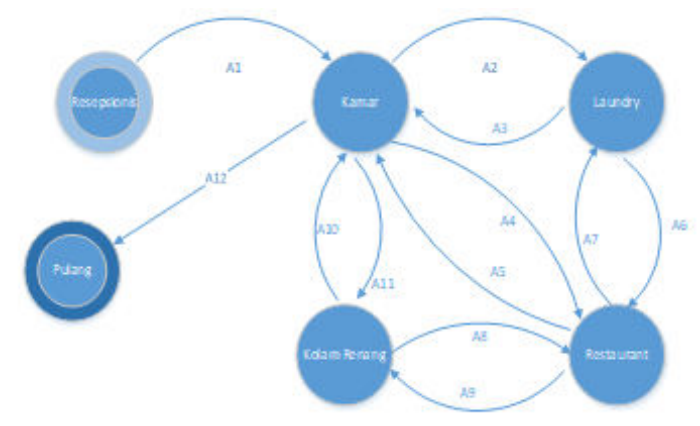

Gambar 7. FSM perilaku tamu.

Pada Gambar 7 A1 merupakan ketika tamu sudah berdiri di depan resepsionis selama 2 detik maka tamu akan pergi ke kamar yang kosong. A2 jika tamu ingin pergi ke laundry. A3 jika tamu ingin balik ke kamar. A4 Jika tamu ingin pergi ke restoran. A5 jika tamu ingin balik kamar. A6 jika tamu ingin pergi ke restoran. A7 jika tamu ingin pergi ke laundry. A8 jika tamu ingin pergi ke restaurant. A9 jika tamu ingin pergi ke kolam renang. A10 jika tamu ingin balik ke kamar. A11 jika tamu ingin pergi ke kolam renang. A12 jika tamu ingin pulang. Banyakanya keinginan tamu dirandom ketika tamu datang. Ketika tamu memasuki fasilitas maka keinginan berkurang 1 . Jika keinginan habis tamu akan kembali ke kamar dan pulang.

Dalam permainan terdapat pegawai yang melayani tamu. Perilaku pegawai ketika idle menunjukan pegawai tidak melakukan aktifitas. Tetapi jika ada tugas pegawai akan berkerja. Jika pegawa dipecat maka pegawai akan pulang. Gambar 8 memperlihatkan FSM perilaku pegawai.

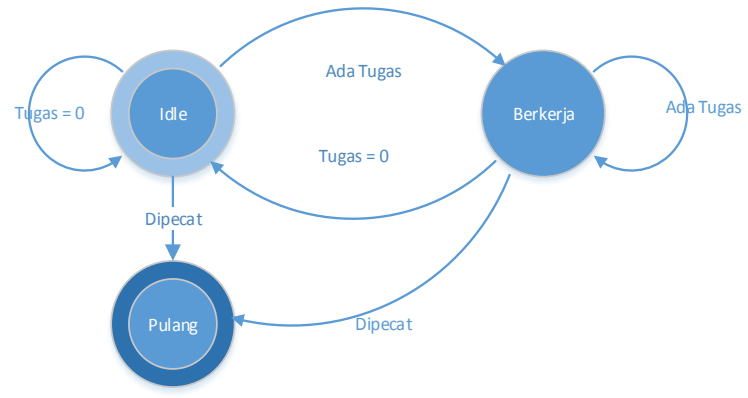

Gambar 8. FSM perilaku pegawai.

Pada permainan simulasi manajemen hotel ini terdapat maling yang akan merugikan pemain jika pemain tidak segera merekrut satpam. Maling akan berjalan mengelilingi setiap kamar yang ada pada lantai 1 tetapi jika ada satpam maling akan segera tertangkap. Berikut Gambar 9 yang memperlihatkan FSM perilaku maling.

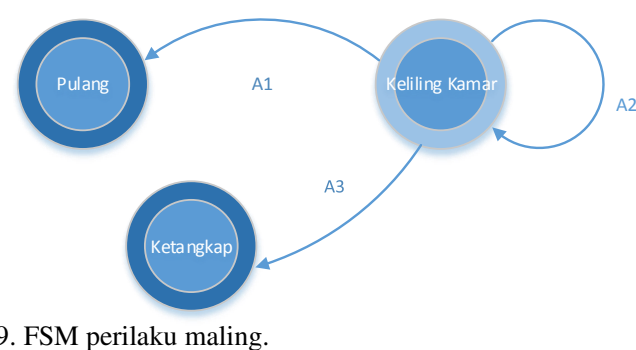

Gambar 9. FSM perilaku maling.

\section{B. Peraturan Permainan}

Dalam permainan simulasi manajemen hotel terdapat peraturan sebagai berikut:

1. Pemain diberikan modal sebanyak Rp200.000.000

2. Pemain bebas membangun fasilitas dan menempatkannya dimana saja, terbatas dengan fasilitas yang ada dan jumlah koin.

3. Pemain bebas merekrut karyawan terbatas jumlah koin.

4. Pemain dapat memperluas hotel dengan meningkat bangunan atau membeli tanah dengan koin yang pemain punya.

5. Harga perluasan hotel akan semakin naik ketika pemain memperluas hotel.

6. Pemain bebas memecat karyawan. 


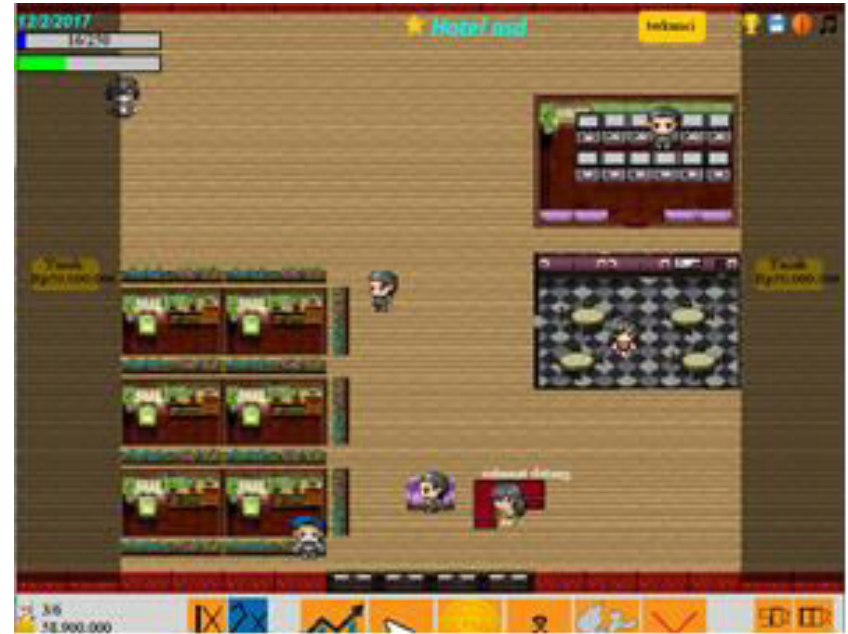

Gambar 10. Tampilan Permainan.

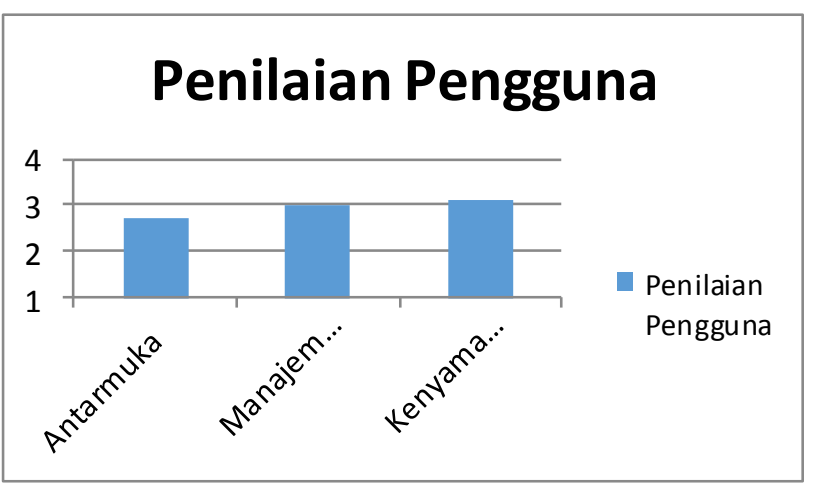

Gambar 11. Hasil Pengujian Pegguna.

7. Pemain dapat melihat emoticon mood pegawai tetapi tidak dengan persentasenya.

8. Karyawan yang berkerja terus menerus moodnya akan berkurang dan akan berpengaruh kepada kecepatan kerja karyawan.

9. Karyawan akan meningkat moodnya jika sedang tidak berkerja.

10.Pemain dapat melihat status kepuasan tamu dengan mengarahkan cursor ke tamu.

11.Pemain dapat meningkatkan kepuasan tamu dengan melengpkapi fasilitas hotel, memperindah hotel dengan membangun dekorasi serta melayani tamu dengan baik melalui karyawan yand diperkerjakan.

12. Reputasi hotel akan bertambah jika tamu tidak kecewa, sebaliknya jika tamu kecewa maka reputasi hotel akan berkurang.

13.Untuk mencapai bintang 3 pemain harus meningkatkan reputasi sebanyak 250 untuk mencapai bintang 5 pemain harus menigkatkan reputasi sebanyak 1000.

14.Pemain dapat melihat peluang datangnya tamu dengan melihat status keantusian.

15.Pemain bisa mengatur harga sewa dengan memilih tombol menu atur harga sewa.

16.Pemain akan kalah jika koin memiliki nilai 0 atau minus selama 3 bulan dikarenakan tidak adanya tamu yang datang.

17. Gambar 10 memperlihatkan tampilan permainan simulasi manajemen hotel.
Tabel 2

Hasil Pengujian Blackbox

\begin{tabular}{|c|c|c|c|}
\hline ID & Deskripsi & State & $\begin{array}{l}\text { Perilaku } \\
\text { Terlaksana }\end{array}$ \\
\hline $\begin{array}{l}\text { UF- } \\
001\end{array}$ & $\begin{array}{l}\text { Uji Coba pada } \\
\text { Halaman Menu } \\
\text { Utama }\end{array}$ & $\begin{array}{l}\text { Halaman Awal, pada } \\
\text { FSM permainan }\end{array}$ & $\mathrm{Ya}$ \\
\hline \multirow[t]{2}{*}{$\begin{array}{l}\text { UF- } \\
002\end{array}$} & $\begin{array}{l}\text { Uji Coba pada } \\
\text { Halaman } \\
\text { Informasi }\end{array}$ & $\begin{array}{l}\text { Halaman informasi, } \\
\text { pada FSM permainan }\end{array}$ & $\mathrm{Ya}$ \\
\hline & $\begin{array}{l}\text { Uji Coba pada } \\
\text { Halaman } \\
\text { Permainan }\end{array}$ & $\begin{array}{l}\text { Halaman Permainan, } \\
\text { pada FSM Permainan, } \\
\text { FSM Kondisi Tamu, } \\
\text { FSM Kondisi Pegawai, } \\
\text { FSM Memperluas } \\
\text { Hotel, FSM Merekrut } \\
\text { Pegawai, FSM Maling }\end{array}$ & $\mathrm{Ya}$ \\
\hline \multicolumn{4}{|l|}{$\begin{array}{l}\text { UF- } \\
003\end{array}$} \\
\hline $\begin{array}{l}\text { UF- } \\
004\end{array}$ & $\begin{array}{l}\text { Uji Coba pada } \\
\text { Perilaku Tamu }\end{array}$ & $\begin{array}{l}\text { Tamu, pada FSM } \\
\text { Perilaku Tamu }\end{array}$ & $\mathrm{Ya}$ \\
\hline $\begin{array}{l}\text { UF- } \\
005\end{array}$ & $\begin{array}{l}\text { Uji Coba pada } \\
\text { Perilaku Pegawai }\end{array}$ & $\begin{array}{l}\text { Pegawai, pada FSM } \\
\text { Perilaku Pegawai }\end{array}$ & $\mathrm{Ya}$ \\
\hline $\begin{array}{l}\text { Uf- } \\
006\end{array}$ & $\begin{array}{ll}\text { Uji } & \text { Coba } \\
\text { Simulasi } & \text { pada } \\
\text { Halaman } & \\
\text { Bangkrut } & \end{array}$ & $\begin{array}{l}\text { Halaman Bangkrut, } \\
\text { pada FSM permainan }\end{array}$ & $\mathrm{Ya}$ \\
\hline
\end{tabular}

\section{PENGUJIAN DAN HASIL}

Pengujian yang dilakukan pada penelitian ini adalah pengujian blackbox dan pengujian pengguna. Pengujian ini berfungsi sebagai pengujian fungsionalitas dan pengujian subjektif yang bertujuan untuk mengetahui tingkat keberhasilan aplikasi yang dibangun.

Pengujian dengan metode blackbox menguji FSM pada permainan. Dari data yang didapatkan permainan telah berhasil mengimplementasikan simulasi dalam bentuk FSM. Berikut rekapitulasi pengujian blackbox akan dijelaskan pada Tabel 2.

Dalam melakukan pengujian pengguna, penguji yang telah diberikan informasi seputar aplikasi diminta mencoba menggunakan perangkat lunak untuk mencoba semua fungsionalitas dan fitur yang ada. Serta untuk mencoba sampai tingkat berapakah pengguna bisa mengoperasikan hotel.

Jumlah pengguna yang terlibat dalam pengujian perangkat lunak sebanyak lima belas orang untuk pengujian fungsionalitas, performa dan antarmuka. Dalam melakukan pengujian, pengguna melakukan percobaan lebih dari satu kali.

Uji coba yang dilakukan terhadap beberapa pengguna memiliki beberapa aspek yang dipisahkan antarmuka, manajemen hotel, dan tingkat kenyamanan. Sistem penilaian didasarkan pada skala penghitungan satu sampai empat di mana skala satu menunjukkan nilai terendah dan skala empat 
menunjukkan skala tertinggi. Penilaian akhir kemudian dilakukan dengan menghitung berapa banyak penguji yang memilih suatu skala tertentu dan kemudian dicari nilai rataratanya. Dari penilaian proses simulasi manajemen hotel berjalan dengan cukup sesuai dengan kondisi nyata. Hasil uji coba dipaparkan pada Gambar 11.

\section{KESIMPULAN}

Dari semua proses pengerjaan penelitian kesimpulan yang didapatkan sebagai berikut:

1.Penerapan permainan simulasi manajemen hotel telah diusahakan sesuai seperti kondisi nyata, dibuktikan dengan nilai 3.01 dari skala 4 yang dapat dilihat pada pengujian pengguna parameter manajemen hotel.

2. Penentuan aturan main dan skenario permainan berdasarkan pada faktor-faktor yang ada dalam proses manajemen hotel yaitu pemain harus menjaga keamanan, kebersihan, dan pelayanan tamu dengan merekrut pegawai. Serta menjaga kenyamanan tamu dan melengkapi fasilitas hotel.
3. Berdasarkan hasil uji coba blackbox FSM telah diimplementasikan pada alur permainan manajemen hotel, perilaku tamu dan perilaku pegawai hotel dimana setiap FSMnya mempunyai state, event dan action.

\section{DAFTAR PUSTAKA}

[1] J. Umbaran, "PENGERTIAN, METODE, DAN JENIS-JENIS SIMULASI."

[2] "What is Hotel Management and Why it is a good career option?" [Online]. Available: http://www.ipsacademy.org/what-is-hotelmanagement/. [Accessed: 17-Jan-2018].

[3] "GameMaker," Yoyo Games. [Online]. Available: http://www.yoyogames.com/gamemaker. [Accessed: 11-Dec-2017].

[4] "Finite-State Machines: Theory and Implementation," Game Development Envato Tuts+. [Online]. Available: https://gamedevelopment.tutsplus.com/tutorials/finite-state-machinestheory-and-implementation--gamedev-11867. [Accessed: 22-Jan-2018].

[5] "Klasifikasi Hotel Berdasarkan Bintang." [Online]. Available: http://jenishotel.info/klasifikasi-hotel-berdasarkan-bintang. [Accessed: 22-Jan-2018].

[6] Hotel Netral interview. 2017. "Interview of Hotel Management". Jl. RE. Martadinata No.124, Jombang. 